\title{
Activities That May Influence the Risk of Crocodile (Crocodylus Acutus: Reptilia: Crocodilidae) Attack to Humans in the Tempisque River Area, Guanacaste, Costa Rica.
}

\begin{abstract}
Actividades que pueden influir en el riesgo de ataque de cocodrilos (Crocodylus acutus: Reptilia: Crocodilidae) a humanos en el área del Río Tempisque, Guanacaste, Costa Rica.
\end{abstract}

Iván Sandoval-Hernández

ivan.sandoval.hernandez@una.cr

Escuela de Ciencias Biológicas. Universidad Nacional

Heredia, Costa Rica.

Alejandro Duran-Apuy

alejandro d a@yahoo.com

Escuela de Ciencias Biológicas. Universidad Nacional

Heredia, Costa Rica.

Jacqueline Quirós-Valerio

shiaky0890@gmail.com

Escuela de Ciencias Biológicas. Universidad Nacional

Heredia, Costa Rica.

Recibido-Received: 10/dic/2015 / Corregido-Corrected: 16/may /2016.

Aceptado-Accepted: 20/ago/2016 / Publicado-Published: 31/ene /2017.

\begin{abstract}
Resumen
Una de las mayores poblaciones de cocodrilos de Costa Rica se encuentra en el río Tempisque. La especie está amenazada por la pérdida de hábitat y la cacería, sin embargo, sus poblaciones han crecido debido a la protección otorgada por ley. El estudio se realizó en Guanacaste, Costa Rica. Se hizo una caracterización del conocimiento popular, actividades realizadas y percepciones de 374 residentes de la zona de estudio. Se encontró que el 55\% piensa que el cocodrilo es abundante, $70 \%$ cree que las poblaciones han aumentado. Las actividades más peligrosas efectuadas son principalmente la recreación, natación y pesca artesanal. Entre ellas se encontraron diferencias significativas entre las proporciones de respuesta $\left(\mathrm{X}^{2}: 71, \mathrm{n}: 10, \mathrm{p}<0.0001\right)$. Estas actividades se realizan diariamente $(25 \%)$, semanalmente $(30 \%)$, mensualmente $(18 \%)$, anualmente $(10 \%)$. No se reconocen los riesgos de ataque ni la densidad de cocodrilos en el río. Así mismo, se muestra una falta de conocimiento acerca la historia natural y ecología de la especie. Las razones de ataque son: la agresividad de los animales y su densidad, encontrándose diferencia entre las respuestas sobre las razones del ataque $\left(\mathrm{X}^{2}: 35, \mathrm{n}: 8\right.$ $\mathrm{p}<0.0001)$. En general, la percepción de cocodrilo es desfavorable.
\end{abstract}

Palabras claves: Cocodrilo; Riesgo de ataque; Densidad de población; Costa Rica; Río Tempisque. 
UNICIENCIA Vol. 31, No. 1, pp. 13-22. Enero-junio, 2017.

ISSN Electrónico: 2215-3470

URL: www.revistas.una.ac.cr/uniciencia

DOI: $\underline{\text { http://dx.doi.org/10.15359/ru.31-1.2 }}$

Email: revistauniciencia@una.cr

\begin{abstract}
One of the largest populations of crocodiles in Costa Rica is located at the Tempisque River. The species is threatened by habitat loss and poaching; but its populations have grown due to the protection given by law. The research was conducted in Guanacaste, Costa Rica. We made a characterization of popular knowledge, activities and perceptions of 374 residents of the study area. It was found that $55 \%$ believe that the crocodiles are abundant, $70 \%$ believe that populations have increased. The most dangerous activities done are recreation, swimming and fishing. There are significant differences between the proportions of response $\left(\mathrm{X}^{2}: 71, \mathrm{n}=10, \mathrm{p}<0.0001 \mathrm{X} 2\right)$. These activities are done daily $(25 \%)$, weekly (30\%), monthly (18\%) and annually (10\%). The risk of attack and the crocodile's density in the river are not recognized. Also, a lack of knowledge about the natural history and ecology of the species is shown. The reasons for attacks are: the aggressiveness of the animals and their density. There are differences in the responses on the reasons of the attacks $\left(\mathrm{X}^{2}: 35, \mathrm{n} 8 \mathrm{p}<0.0001\right)$. Generally, the crocodile perception is unfavorable.
\end{abstract}

Keywords: Crocodile, risk of attack, population density; Costa Rica; Tempisque River.

The Tempisque River has been recognized for hosting the largest crocodile population (Crocodylus acutus) in Costa Rica, and in terms of relative abundance, it is just behind the Tarcoles River. However, for more than four decades, illegal hunting and poaching led them to the brink of extinction (Thorbjarnarson, 1989). The species is currently designated as vulnerable according to the IUCN Red List, and it is in Appendix I of CITES (Bolaños et al., 1997; Sánchez, 2001).

Despite this situation, the crocodile populations in the Tempisque River have grown considerably, aided mostly by the protection given by the law and repopulation actions carried out in the last 15 years (Sánchez, 2001). This is corroborated by studies conducted for several years. These studies showed that, in the main channel of the river, the crocodile population has tripled, and this despite the human population growth, the advancing agricultural frontier, the urban pressure and the improvement of the road network (Bolaños et al., 1997; Sánchez, 2001; Bolaños 2011a; Bolaños 2011b; Bolaños 2012a; Bolaños 2012b; Orozco, 2015).

Consequently, more interactions between humans and crocodiles were generated, which have resulted in an increase in the number of attacks on residents of coastal communities (Fonseca, 2008). In the last three years, more attacks have been reported; previously one or two attacks per year were reported, while, at present, two to three incidents are reported (Fonseca, 2008). In Costa Rica, since 1995, there have been 13 fatal accidents (seven in the last five years), and 15 nonfatal (eight in the last five years), involving humans and crocodiles (Bolaños, 2012a), According to Fonseca (2008), the Tempisque River area is one of the places where we can have more accidents.

In this regard, Balaguera \& González (2010) have found conflicts between humans and crocodiles. In neighboring towns of the Tempisque River, almost $82 \%$ of surveyed people consider crocodiles as dangerous and aggressive animals, with abundant populations (Valdelomar et al., 2012). This situation becomes even more troubling, considering that in each of these clashes, residents have shown ignorance in relation to the characteristics, ecology and natural history of this animal (Hernández, 2007; Valdelomar et al 2012; Morales, 2013; Orozco, 2015).

In general, residents tend to underestimate the danger of certain areas and live near them. Besides, they swim in rivers or in ponds inhabited by the species. According to Valdelomar et al. (2012), Morales (2013), and Orozco (2015), in general, residents do not know the exact reasons of crocodile attacks, situation that can result in an increase of interactions between humans and crocodiles. 
Bolaños (2011a, 2011b, 2012a, 2012b) has identified a considerable variation in landscape composition in the Tempisque River area (the habitat of the crocodile), due to human activities, change in the forest coverage and the emerging of crops. This led to a loss of natural habitat, which can also cause the decrease of many of potential prey and intra-specific crocodile competitors; in addition, crocodiles are increasingly in contact with people (Pooley et al. 1989, Bolaños 2012a, Bolaños 2011b).

Another important aspect Bolaños (2012b) and Orozco (2015) also point out is the high density of crocodiles in this area, and the variation in the sex ratio (from one male for each female, to a current status of 3.3 males for every female), a serious situation for the population since the expected ideal ratio in a normal environment is approximately one or two females per male (Joanen \& McNease, 1980).

The sexual ratio skewed to males and the territorial behavior of the species are the probably reasons that a significant number of breeding males are expelled from their sites and migrate looking for new territories (probably low quality ones). Animals rejected from their actual sites caused a movement of subordinate individuals that must seek territories in areas outside their usual territories. Rejected crocodiles are moving toward territories where it was not common to watch them; this could increase the number of interactions between crocodiles and humans (Child 1987, Bolaños 2012a, Bolaños 2012b). Because of all of this, the aim of this work is to carry out a characterization of popular knowledge, activities done in or close to the river, and perceptions of residents about crocodiles to identify the activities that may influence the risk of crocodile attack on people at the Tempisque River area, in Guanacaste, Costa Rica.

\section{Methodology}

The research took place in Cañas, Carrillo, Liberia, Bagaces and Santa Cruz counties, in the province of Guanacaste, Costa Rica, in the surrounding towns of the Tempisque River area, in order to cover the high and medium crocodile habitat in the region (Figure 1).

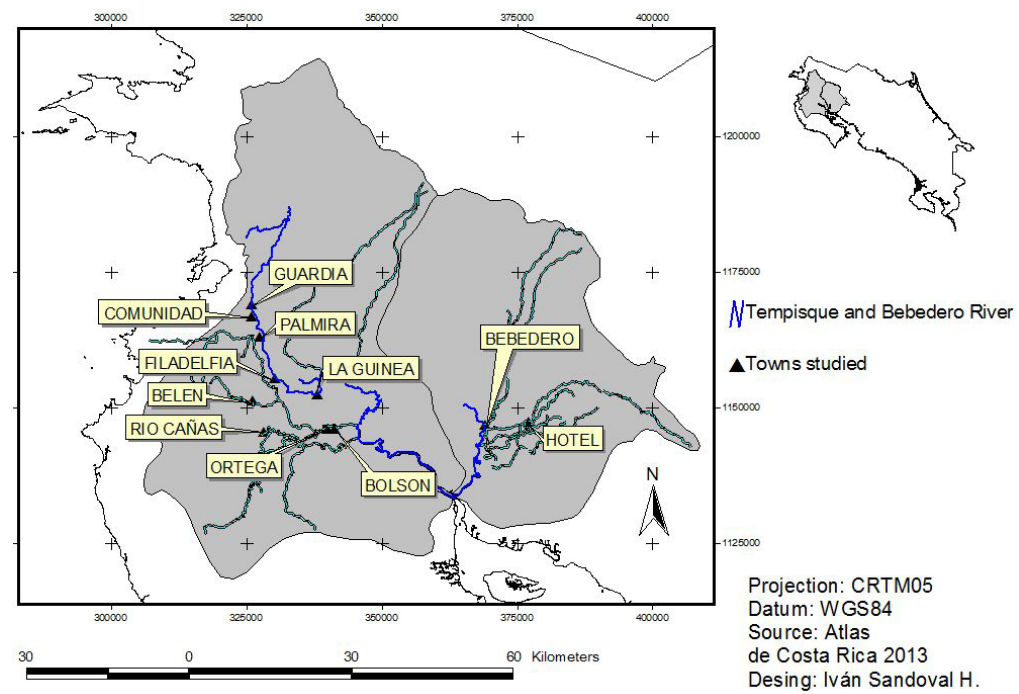

Figure 1. Towns studied in the Tempisque River areas. Guanacaste, Costa Rica. Note: From this research. 
A semi-structured survey was conducted door to door in the first week of May 2013. To set the number of respondents per site, the size of the town and the number of people in the survey design were considered. We administered 34 questionnaires (19 questions) in each town (374 in total in the 11 towns inside the study area). Besides that, we organized three workshops with school children (108 with ages between seven to twelve years old) in the communities of Bebedero, Ortega, and Bolson to measure the knowledge about the species and its importance to them.

As mentioned, we worked with residents (schoolchildren, adults, men and women), assuming that everyone would have the same probability of being attacked by a crocodile because they inhabit the same place. The survey was designed to assess the activities that may influence the risk of crocodile attack on people.

The information collected was plotted and analyzed descriptively, also to determine differences between the responses values, with a Kolmogorov $(\mathrm{K})$ goodness of fit test; besides, a non-parametric Kruskal Wallis (KW) variance analysis was performed. For all statistics, a p value below 0.05 was considered as statistically significant.

\section{Results}

We found that the main activities done by the residents are grouped in ten categories. Artisanal fisheries (30\%), swimming (20\%), gutting fish (17\%), and recreation (17\%) are the most important (Graphic 1). Between the ten categories there are significant differences in the answers proportion $\left(\mathrm{X}^{2}: 71, \mathrm{n}: 10, \mathrm{p}<0.0001\right)$. The results showed that people were willing to do these activities very often (daily $25 \%$, weekly $30 \%$, and monthly $18 \%$ ).

Graphic 1.

Activities done by residents that may influence the risk of crocodile (Crocodylus acutus) attack in the Tempisque River area, Guanacaste, Costa Rica. Note: From this research.

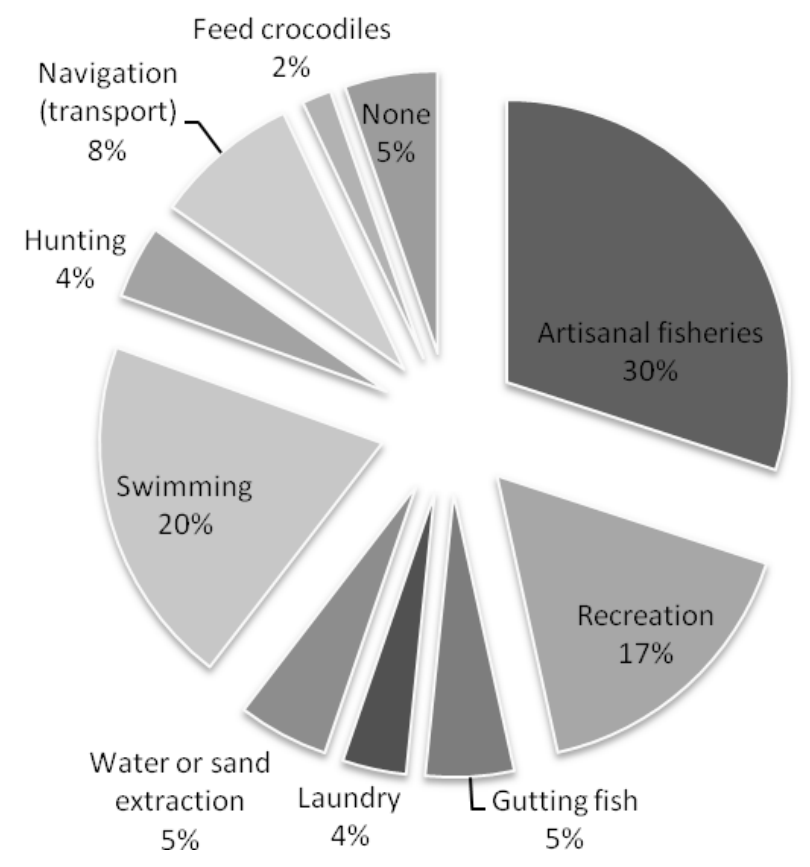


The residents showed a lack of knowledge about the crocodiles natural history, mating, courtship, nesting seasons, territorialism, crocodile feeding and the habitat in general. Thus, about the risks of attacks, they did not know the reasons why crocodiles attack (dangerous animals $42 \%$, hunters $6 \%$, breeding season $3 \%$, human recklessness $6 \%$, feeding $5 \%$, crocodile density $22 \%$, and habitat loss $1 \%$ ). We found differences between the answers about reasons of attacks ( $\left.\mathrm{X}^{2}: 35, \mathrm{n}: 8 \mathrm{p}<0.0001\right)$.

In general, data show no significant difference between the perceptions of risks, by gender, in the studied area (men: KW: H: 8.35, gl: 9 P:0.47; women: H:9.18, gl:9 P: 0.41). Small differences were found in places where crocodile attacks occurred, such as Rio Cañas and Bebedero, in comparison with locations without crocodile attacks where people feel less risk of attack (Palmira and Comunidad towns) (Graphic 2).

Graphic 2.

Risk of attack of crocodiles (Crocodylus acutus) in the Tempisque River area, Guanacaste, Costa Rica. Note: From this research.

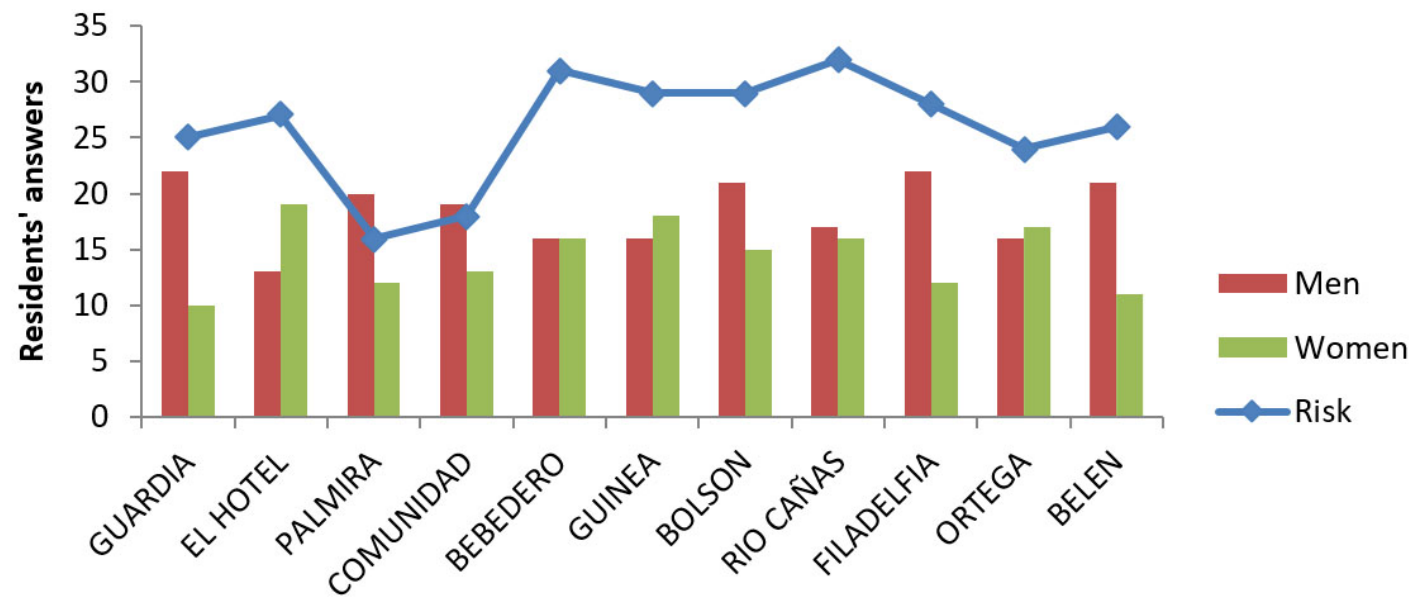

Towns studied

It is important to recognize that in most communities the human-crocodile conflict is common, as Graphic 3 shows; people identified domestic animals and persons as the main preys of the crocodiles and left the known preys, such as the aquatic and the wild terrestrial animals, in the last place. Besides that, once the answers about whom crocodiles attack more were analyzed, data clearly showed that more men suffered attacks in the area, with the exception of Bebedero where kids have been attacked (Graphic 4). 
UNICIENCIA Vol. 31, No. 1, pp. 13-22. Enero-junio, 2017.

Graphic 3.

Main preys of crocodiles (Crocodylus acutus) identified by the residents in the Tempisque

River area, Guanacaste, Costa Rica. Note: From this research.

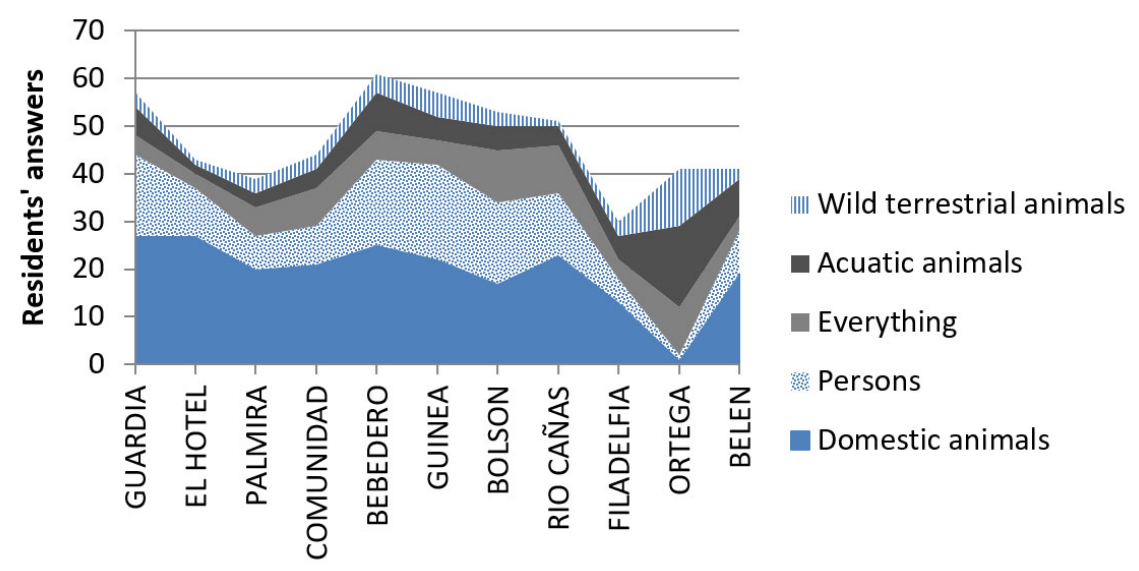

Towns studied

Although residents recognized the crocodile as abundant and aggressive species $(43 \%$, 161 respondents), just a few people identified the mating season (3\%, 11 respondents), the crocodiles' search for food (4\%, 15 respondents), human recklessness (6\%, 22 respondents), and the closeness of the river shore as the reasons for the attacks. Near than a quarter of the surveyed population $(22 \%, 82$ respondents) said that the attacks were due to the high density of the species, and $16 \%$ (60 respondents) did not know the reasons.

Graphic 4.

Residents' perception of crocodile attacks (Crocodylus acutus) to humans in the Tempisque River area, Guanacaste, Costa Rica. Note: From this research.

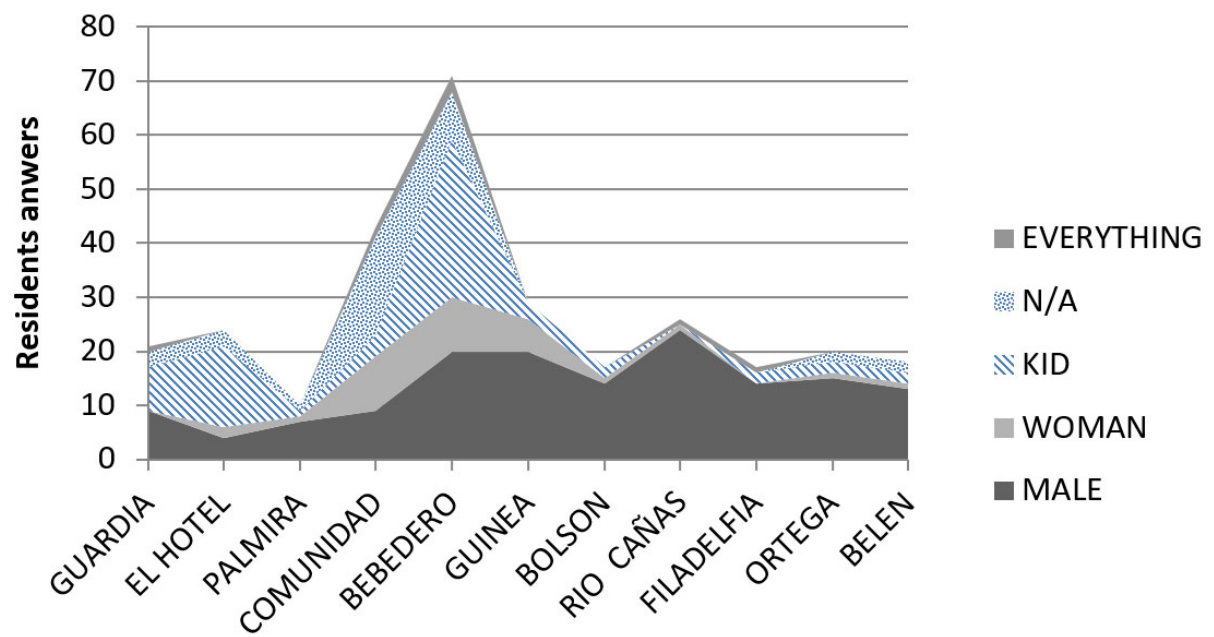

Towns studied 
About the crocodiles density in the river, $55 \%(n=206$ respondents $)$ thought that there is a large number of these animals; $35 \%(n=131$ respondents) said that there are a few ones; $6 \%(n=$ 23 respondents) said that there are none; and 4\% didn't know or answer. When we asked if the number of crocodiles had increased in the last ten years, $70 \%$ ( $n=262$ respondents) said yes; $23 \%$ ( $\mathrm{n}=86$ respondents) no; and the last $7 \%$ didn't know ( $\mathrm{n}=26$ respondents). Among the precautions residents took to prevent attacks, almost $58 \%$ said not to approach the river, and $16 \%$ avoided places where crocodiles live; $11 \%$ said to be careful; almost $4 \%$ said not to disturb the animals and to swim in shallow waters; $2.5 \%$ did not know; and the last $2.5 \%$ said to kill them.

When we asked if they had received any information about the crocodiles, $80 \%$ of surveyed residents responded negatively; approximately the same proportion said that they were interested in environmental education activities. According to the answers, in general we found a high similarity between the communities, above $80 \%$ in many of them. The only community with lower similarity values was Ortega.

Finally, the work with the schools showed that children in two communities (Bebedero and Ortega) had a high knowledge about the importance of the species (mostly because they know about its use and its "medicinal properties"), but had a vague idea about mating season, feeding, and the habitat. The perception in general about the crocodile is unfavorable.

\section{Discussion}

The type of activities done by communities around the Tempisque River and its frequency could significantly increase the risk of attacks, also considering that there are river areas where crocodiles are abundant. This contrasts with the apathy and the confidence sense observed in a segment of the studied towns, especially in villages where attacks are not common or river distance is greater, as mentioned by Valdelomar et al. (2012). As the study revealed, the lack of knowledge that many respondents expressed about the identification of hazardous areas, the crocodile natural behavior, in general and during the breeding season, is the evidence showing that people ignore the risk involved in activities such as swimming, fishing, and laundry in the river margins; this is consistent with what was found in the same area by Valdelomar et al. (2012), Morales (2013) and Bolaños (2011a), Bolaños (2011b).

In this matter, and as a possible explanation for the development of those activities in the riverbed, we can mention the financial need because, as Sánchez (2001) indicated, the river used to provide economic incentives for many families in these communities, which depended on activities such as fishing, transportation and recreation (tourism) to cover basic needs like housing and food. So, this suggests that people (mostly men) are willing to accept the risk rather than to ensure their own safety.

When we analyzed the perception about crocodile attacks, it was important to note that the C. acutus population has been increasing (Bolaños 2012a, Bolaños 2012b, and Orozco 2015). Likewise, there has been an increase in the development of infrastructure in the study area, leading to a higher concentration of people in crocodile distribution areas, which can generate the exposure to a greater number of crocodiles.

Moreover, nowadays fisheries and crops generate a high pressure on freshwater aquatic systems that $C$. acutus requires to maintain the balance of its basic ecological conditions and its populations; this can lead the species to move around in areas dominated by anthropic activities 
(Menacho, 2001; Hernandez, 2007; Bolaños et al. 1997, Bolaños 2011a, Bolaños 2011b, Bolaños 2012a, Bolaños 2012b).

As mentioned, due to this pressure, at present, it is common to see crocodiles moving to lower quality habitat sites, such as crops irrigation canals, streams, intermittent ponds, flooded lagoons, and fisheries among others; and this resulting in a feeling of closeness that can be easily interpreted as an increase in the number of individuals in all these areas (Bolaños 2011a, Bolaños 2011b, Bolaños $\underline{2012 b}$, Valdelomar et al. 2012, Morales, 2013). Likewise, the increase in the number of attacks may be linked to the same subject due to the fact that, because of competition, many individuals may be moving out of their preferred habitats and can be generating attacks on the periphery of their distribution, in areas where it was difficult to see these animals in the past (Bolaños 2012a).

In this matter, in communities with a greater proximity to the river, such as Filadelfia, Bebedero, La Guinea, and the Hotel, it was found a sense of constant risk of attack; a similar situation was reported by Valdelomar et al. (2012) in the same area, and by Morales (2013) in the wetlands near Tempisque River.

In general, Bolaños (2012b) found, in the study area, an increase in crocodile populations, which can justify the people's perception on the high number of individuals and the high level of risk; this may also be associated with the increase in the sense of danger, sightings, and attacks. In communities like Belen, Guardia and Palmira, located at a some distance from the main river channel or where river conditions are not optimal for crocodile distribution, the perception of the risk is relatively low, and this may be explained by the amount of crocodiles in these areas, again coinciding with quotes by Valdelomar et al. (2012) and Bolaños (2011a), Bolaños (2011b).

The main reasons explaining why people in Rio Cañas, Bebedero, La Guinea, and Bolson consider crocodiles as dangerous may be due to the amount of attacks occurred in these communities (Valdelomar et al. 2012, Bolaños 2011a, Bolaños 2012b), and by the lack of knowledge about the species ecology and natural history, its habitat requirements and aggressiveness (Morales, 2013; Bolaños, 2011a; Bolaños, 2011b; Bolaños, 2012b).

In relation to the species control and management, all communities believe that the most effective way to prevent an attack is not be close to the river, what is not consistent with what they do because, as we found, people invested much of their time in activities in or near the riverbed (Valdelomar et al., 2012; Morales, 2013). Also, as Hernández (2007) said, attacks on humans happened when they invaded the crocodile territory, protection zones and mangroves. Since people are unable to avoid approaching these areas because of their needs, it is really important to pay attention to the situation because they are choosing other solutions to diminish the conflicts with the crocodiles, such as killing the animal, situation that is evident in our results.

When we analyzed the human-crocodile conflict, there were a high percentage of people who claimed to have never received information about mitigating the risk of attacks. This reflects an inefficient communication process between scientists, environmental educators, Ministry of Environment, wildlife managers, and those who really need the information (the communities) (Valdelomar et al. 2012; Morales, 2013; Bolaños, 2012b).

However, more than half of respondents, despite their dissatisfaction, become interested in receiving information, what is consistent with Morales (2013) results. This could also be seen as an important starting point in the development of the species management at the Tempisque river area (Bolaños, 2011a). 
It is important to mention that the work with schools has coincidence with the communities' answers. As well, there is a similarity between most of the items analyzed among all the communities; the similarity percentages could be due to the closeness of the locations. In addition, they all are located in areas of crocodile distribution. In general, similar problems were pinpointed and have been identified by Bolaños (2011a), Bolaños (2011b), Valdelomar et al. (2012) and Morales (2013) too.

\section{Acknowledgements}

Kattia Alpizar, Verónica Araya, Oscar Araya, Gette Arce, José Cambronero, David Mattey, María Méndez, Jonathan Navarro, Priscilla Obando, Ana Rodríguez, Gabriela Salas, María Sánchez, Marcela Sánchez, Katherine Sánchez, María Trejos, Cinthya Vega, for their collaboration in the data collection process.

\section{References}

Balaguera-reina, S. A., \& González-maya, J. F. (2010). Percepciones, conocimiento y relaciones entre los Crocodylia y poblaciones humanas en la Vía Parque Isla de Salamanca y su zona de amortiguamiento, Caribe colombiano. Latin American Journal of Conservation, 1(1), 53-63.

Bolaños J. (2012a). Manejo de cocodrilos (Crocodylus acutus) en estanques de cultivo de tilapia en Cañas, Guanacaste", Ambientales 43, 63-72. http://dx.doi.org/10.15359/rca.43-1.6

Bolaños, J. (2011a). Plan Estratégico para el Manejo de la población de Crocodylus acutus (cocodrilo americano), en el Gran Humedal Tempisque. Sistema Nacional de Áreas de Conservación. Dirección Regional. Área de Conservación Arenal Tempisque. Documento técnico. 20 p.

Bolaños, J. (2011b). Propuesta plan de contingencia en el manejo de la población de cocodrilos del gran humedal del Tempisque. Asociación Especialistas en Crocodílidos - Centro América. Documento técnico.

Bolaños, J. (2012b). Survey of American Crocodiles in Tempisque Great Wetlands, Guanacaste, Costa Rica. Crocodile Specialist Group Newsletter. 31 (1): 2-7

Bolaños, J. R., J. Sánchez \& L. Piedra. (1997). Inventario y estructura poblacional de crocodílidos en tres zonas de Costa Rica. Rev. Biol. Trop. 45(1), 283-287.

Child, G. (1987). The Management of Crocodiles in Zimbabwe. Pp. 49-62. In: G. J. W. Webb, S. C. Manolis, and P. J. Whitehead (editors). Wildlife Management: Crocodiles and Alligators. Surrey Beatty \& Sons Pty Limited, Chipping Norton, Australia. 552 pp.

Fonseca, A. (2008). Decimocuarto Informe del Estado de la Nación en Desarrollo Humano Sostenible. Capítulo 4: Armonía con la naturaleza. La zona marino costera. San José, Costa Rica.

Hernández, J. (2007). Convivir con nuestros cocodrilos. Revista mensual sobre la actividad ambiental, Ambientico. No 166 11-13pp.

Joanen, T. and L. McNease. (1980). Reproductive Biology of the American Alligator in Southwest Louisiana. Proceedings of the Society for the Study of Amphibians and Reptiles Symposium: Reproductive Biology and Diseases of Captive Reptiles 1:153-159.

Menacho, R. M. (2001). Turismo y vida silvestre en humedales del Tempisque. Ciencias Ambientales. 21: 13-22.

Morales, A. (2013). Percepciones y conocimiento popular sobre cocodrilos (Crocodylusacutus) en las zonas aledañas al río Tempisque, Costa Rica. Biocenosis, 27 (1-2), 71-76.

Orozco, W. (2015). Monitoreo de la población de cocodrilos (Crocodylus acutus) en el río Tempisque. Guanacaste. Costa Rica. 2011-2014. Informe final de Práctica Dirigida para optar por el título de Bachiller en Manejo de Recursos Naturales. Universidad Estatal a Distancia (UNED). San José. Costa Rica. 43p. 
UNICIENCIA Vol. 31, No. 1, pp. 13-22. Enero-junio, 2017.

Pooley, A.C., Hines, T. and Shields, J. (1989). Attacks on Humans. Pp. 172-186 in Crocodiles and Alligators. Weldon Owen: New York. pp 172-187

Sánchez-Ramírez, J. (2001). Estado de la población de cocodrilos (Crocodylus acutus) en el río Tempisque, Guanacaste, Costa Rica. INBio, Heredia, Costa Rica.

Thorbjarnarson, J. B. (1989). Ecology of American Crocodile, Crocodylus acutus. pp 228-259. In: International Union for the Conservation of Nature (Ed.). Crocodiles: Their Ecology, Management and Conservation. UICN, Gland, Suiza.

Valdelomar, V., Ramírez-Vargas, M. A., Quesada-Acuña, S. G., Arrieta, C., Carranza, I., Ruiz-morales, G., Espinoza-bolaños, S., et al. (2012). Percepción y conocimiento popular sobre el cocodrilo Crocodylus acutus (Reptilia: Crocodylidae) en zonas aledañas al río Tempisque, Guanacaste, Costa Rica. Cuaderno de Investigación UNED, 4(2), 191-202.

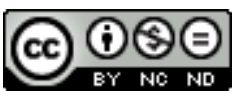

Activities That May Influence the Risk of Crocodile (Crocodylus Acutus: Reptilia: Crocodilidae) Attack to Humans in the Tempisque River Area, Guanacaste, Costa Rica. (Iván Sandoval-Hernández y otros) por Revista Uniciencia se encuentra bajo una Licencia CreativeCommons Atribución-NoComercial-SinDerivadas 3.0 Unported. 